\title{
Learning to change: The rationale for the use of Motivational Interviewing in Higher Education.
}

DOI:

10.1080/14703297.2016.1198714

\section{Document Version}

Accepted author manuscript

Link to publication record in Manchester Research Explorer

\section{Citation for published version (APA):}

Wells, H., \& Jones, A. (2016). Learning to change: The rationale for the use of Motivational Interviewing in Higher Education. Innovations in Education and Teaching International (Print).

https://doi.org/10.1080/14703297.2016.1198714

\section{Published in:}

Innovations in Education and Teaching International (Print)

\section{Citing this paper}

Please note that where the full-text provided on Manchester Research Explorer is the Author Accepted Manuscript or Proof version this may differ from the final Published version. If citing, it is advised that you check and use the publisher's definitive version.

\section{General rights}

Copyright and moral rights for the publications made accessible in the Research Explorer are retained by the authors and/or other copyright owners and it is a condition of accessing publications that users recognise and abide by the legal requirements associated with these rights.

\section{Takedown policy}

If you believe that this document breaches copyright please refer to the University of Manchester's Takedown Procedures [http://man.ac.uk/04Y6Bo] or contact uml.scholarlycommunications@manchester.ac.uk providing relevant details, so we can investigate your claim.

\section{OPEN ACCESS}


(1)

\section{Learning to change: the rationale for the use of motivational interviewing in higher education}

\section{Harvey Wells \& Anna Jones}

To cite this article: Harvey Wells \& Anna Jones (2016): Learning to change: the rationale for the use of motivational interviewing in higher education, Innovations in Education and Teaching International, DOI: 10.1080/14703297.2016.1198714

To link to this article: http://dx.doi.org/10.1080/14703297.2016.1198714

册 Published online: 20 Jun 2016.

Submit your article to this journal $₫$

Q View related articles $\sqsubset$

View Crossmark data \lceil 


\title{
Learning to change: the rationale for the use of motivational interviewing in higher education
}

\author{
Harvey Wells $s^{a}$ and Anna Jones ${ }^{b}$ \\ ${ }^{a}$ Medical School, University of Manchester, Manchester, UK; ${ }^{b}$ Centre for Research in Lifelong Learning, Glasgow \\ Caledonian University, Glasgow, UK
}

\begin{abstract}
Motivational interviewing is a technique developed for use in clinical contexts in order to help people change unhealthy behaviours. However, because it is centred on change, is non-judgemental and collaborative, it is ideal to be adapted for use in teaching. This paper considers the theoretical basis for its use in higher education settings by examining the underpinnings of the technique and the ways in which it fits within thinking about education. We address some of the challenges to the use of motivational interviewing and consider how it can be conceptualised for use in teaching.
\end{abstract}

\section{KEYWORDS}

Motivational interviewing; teaching; change; learning; motivation

\section{Introduction}

The aim of this paper is to explore the applicability of a health care technique to teaching in Higher Education (HE). Motivational interviewing (MI) was developed to help people change unhealthy behaviours by increasing their intrinsic motivation and overcoming resistance to change. We argue that it can be adapted for use in teaching. We explore how an approach developed in health care can be used in education and chart the rationale underpinning this. The background to the interdisciplinary collaboration between the authors is discussed in more detail (Jones \& Wells, 2013).

In an earlier paper, we considered the practical applications of MI for HE (Wells, Jones, \& Jones, 2013). This paper outlined the practical application of Ml in higher education as a means for working with reluctant students. It provided a set of principles and practices for responding to disengaged students in constructive ways using Ml. It provided a pedagogical tool for building confidence and independence in students.

The current paper builds on this by exploring the theoretical basis for MI. It provides the conceptual basis for the earlier, more practical paper. We suggest that any practical tool also needs a sound basis in scholarship and this is what we seek to consider here. We begin by outlining the underpinning theories then examine links with the educational literature. The second section of this paper responds to some of the criticisms we have encountered in disseminating these ideas. We argue that because Ml is focused on change in a non-judgemental context, it is ideal for education.

\section{Motivational interviewing}

Motivational interviewing (Miller \& Rollnick, 2002) was developed to help people change unhealthy behaviours - smoking, excessive drinking, diet and exercise - but there is evidence to support its use with medication management (Gray, Wykes, Edmonds, Leese, \& Gournay, 2004), diabetes (Welch, Rose, \& 
Ernst, 2006) and psychiatric problems (Arkowitz \& Miller, 2008). Health behaviours are difficult to change as immediate gains outweigh the future consequences. Ml is designed to increase internal motivation rather than instil it externally (Miller \& Moyers, 2006). Traditionally, health care professionals try to increase motivation to change by challenging the person's behaviour (Sorrentino \& Higgins, 1996). The assumption is that informing someone of the consequences of their behaviour will result in a change. However, exerting external pressure to change can create a paradoxical decrease in desire to change (Arkowitz \& Miller, 2008). Indeed approaches using persuasion and advice have limited effectiveness in helping people change (Funnell \& Anderson, 2000). In the next section, we explore the theories that underpin $\mathrm{MI}$ and its application to teaching in $\mathrm{HE}$.

\section{Theoretical basis of motivational interviewing}

MI was initially developed in clinical practice as a way to help facilitate change in people who were highly ambivalent (Miller, 1983). Although the exact mechanisms are not known (Frank \& Frank, 1961), there are several theories proposed for the ways in which Ml works. The first is not specific to MI, but proposes the core conditions explain how change is promoted. The second and third theories relate directly to the techniques applied in Ml: exploring and resolving discrepancy promotes change, and how people talk about themselves to others influences the change process.

It is natural to become defensive when confronted, demeaned or threatened (White \& Miller, 2007). Rogers hypothesised that in order to help someone change, it was important to create an atmosphere of safety and acceptance (Rogers, 1951). Accepting people as they are, paradoxically, frees them up to change, whereas insisting that someone must change often stalls the change process. Therefore, empathy and unconditional positive regard are'necessary and sufficient' conditions for change. Evidence supports the strong relationship between therapist empathy and health behaviour outcomes (Miller \& Taylor, 1980). However, there is a key difference between these approaches: client-centred counselling is non-directive, meaning that the client is encouraged to decide the content and direction of therapy, whereas MI is directed towards facilitating change. Sellman, Sullivan, Dore, Adamson, and MacEwan (2001) suggested that Ml does something beyond the core conditions. The technical components of $\mathrm{MI}$ can be explored by considering the theory of cognitive dissonance and self-perception theory.

Cognitive dissonance pertains to the inner discomfort people feel when they simultaneously hold conflicting ideas. Festinger (1957) hypothesised that people are motivated to reduce dissonance by making changes to their lives. Smoking provides a good example: it is known that smoking significantly increases the chance of developing lung cancer yet most people want to live a long healthy life. These conflicting ideas create a discrepancy resulting in dissonance. Ml aims to increase dissonance by creating a discrepancy for the person to want to change, thus becoming more motivated. The conflict resolution hypothesis postulates that resolution of discrepancy occurs when the two opposing sides become integrated (Clarke \& Greenberg, 1986). This is achieved by helping the person explore both sides of behaviour change.

How much dissonance should be elicited? Too little and the person will not be motivated to change; too much and the person become defensive and resistant (Miller \& Rollnick, 2002). The ideal state is 'optimal frustration' (Kohut, 1971) where there is sufficient dissonance to motivate towards change, yet not so much that it evokes resistance. Externally imposed motivations such as direct challenge and confrontation may evoke too much resistance and decrease motivation to change. If someone perceives an infringement to their personal freedom they are likely to increase the behaviour that is causing them problems (Brehm \& Brehm, 1981). Attempting to promote change through coercion is likely to decrease the possibility of change. Clients who expressed resistance in counselling sessions predicted a lack of subsequent behaviour change (Miller, Benefield, \& Tonigan, 1993).

Bem's (1972) self-perception theory argues that people tend to be more committed to that which they hear themselves defend. Moreover, there is research suggesting changes attributed to one's own choice are more likely to last (Davison, Tsujimoto, \& Glaros, 1973) than those attributed to external sources. If the process of change arises from the person themselves, there is a greater likelihood for 
success than if change imposed from elsewhere. Ml argues that behaviour change is more likely if a person verbalises arguments for change -'change talk' (Miller \& Rollnick, 2002). This has been supported by various studies (Aharonovich, Amrhein, Bisaga, Nunes, \& Hasin, 2008; Amrhein, Miller, Yahne, Palmer, \& Fulcher, 2003).

This all suggests an effective approach to dealing with people who are resistant to change is to be person-centred, develop sufficient discrepancy to evoke dissonance but not too much to create resistance, and provide opportunities to allow people to talk themselves into change. Ml achieves this by utilising three key aspects: collaboration, autonomy and eliciting change. We discuss this in the light of the pedagogic literature, exploring the ways in which MI can be applied to education practice.

\section{Collaboration and empowerment}

The basis for $\mathrm{Ml}$ is one of collaboration. Therapist and client are allies in the change process (Miller \& Moyers, 2006). Resistance is less likely to occur if the therapist is supportive rather than directive (Miller et al., 1993). In psychotherapy research, the common factor promoting change is the relationship between therapist and client (Wampold, 2001). The notion of collaboration is a familiar one in education theory from students as participants in the production of knowledge (Dewey, 1916); learning as a social process, where students learn through interaction with an expert other (Vygotsky, 1978); to Knowles' theory of andragogy, in which an educator becomes 'a facilitator of learning rather than a teacher' (Carlson, 1989, p. 14). Collaboration is present in experiential learning (Kolb, 1984) and student-centred learning (Brandes \& Ginnis, 1994).

Empowerment is a theme running through educational thought since Freire (1970). In HE today, the focus is often more on enabling students to have an active role in their own education and to take responsibility for their learning (Frymier, Shulman, \& Houser, 1996; Thomas \& Velthouse, 1990). Writing of learner empowerment, Houser and Frymier (2009) discuss the importance of teacher behaviour in motivating students to perform meaningful and challenging tasks. Social learning that is empowering and collaborative is consistent with much that is current in educational theory. In teaching, MI can encourage collaboration and empowerment though planning goals, taking responsibility and considering options.

\section{Autonomy}

$\mathrm{Ml}$ is grounded in a respect for personal autonomy (Rollnick \& Miller, 1995). It is based upon the principle of honouring independence rather than being prescriptive (Miller \& Moyers, 2006). The notion of autonomy is also central to learning in HE (Boud, 1981; Candy, 1991). Autonomy is the ability and willingness for self-direction, taking appropriate and effective action and managing one's own learning. MI can promote this through enabling the learner to make choices about their own learning and taking responsibility for their actions. Using $\mathrm{MI}$, the teacher enables the learner to change through building self-efficacy rather than teacher control.

\section{Change}

A fundamental precept of $\mathrm{Ml}$ is change. It focuses on eliciting from the person what the change is and the processes by which change might occur rather than imposing the need for change and the means of change upon them. It acknowledges that change is an oscillating process (Mahoney, 1991) in that progress towards change is not steady or linear - one can move towards change then retreat. In a therapeutic situation, change is facilitated by helping someone resolve their feelings of ambivalence and consider ways of self-motivation (Miller \& Rollnick, 2002). Resistance will result if there is a mismatch between the approach and the person's stage of change (Prochaska \& Prochaska, 1991). In an educational setting, change can be the process of gaining new knowledge, understanding and skills, which requires intellectual, emotional and sometimes physical effort. It can also be a process of moving 
away from patterns that are barriers to successful learning. As with $\mathrm{Ml}$, this involves both student and teacher understanding and articulating what this change is and how this can be achieved. The idea of learning as transformation is a central tenet of adult learning (Mezirow, 2000) and can encompass conceptual, behavioural, cognitive, epistemic, affective or ontological change. Change is key in Ml and in a pedagogic context students learn to consider their options for change, to explore the reasons for resistance to change and in collaboration with a teacher or mentor to examine in an autonomous way the pathways to change.

\section{MI in education}

Research into the effectiveness of MI in clinical contexts has been well documented (Miller \& Rollnick, 2002). While there has been research into the use of Ml in education, most of this is with school-age students. McNamara (1992) advocated the use of MI by teachers due to its positive, non-threatening approach to students' reservations. Several writers (Frey, Lee, Small, Seeley, \& Feil, 2013; Reinke, Herman, \& Sprick, 2011; Sheldon, 2010; Shepard, Herman, Reinke, \& Frey, 2014) have outlined use of $\mathrm{Ml}$ in education. Current research supporting the use of $\mathrm{Ml}$ in schools includes: school mental health (Frey, Cloud, Lee, Small, \& Seeley, 2011), special education (Manthey, 2011), disengaged primary age children (Atkinson \& Cryer, 2015), at risk students (Hadraba, 2011; Kittles \& Atkinson, 2009), truancy (Enea \& Dafinoiu, 2009) and academic performance (Strait, Smith, McQuillin, \& Terry, 2012; Terry, Smith, Strait, \& McQuillin, 2013).

There is less research into MI in HE contexts. Daugherty (2008) completed a randomised control trial of MI with 110 university students who were considered at risk. This study shows that MI was more successful at promoting student engagement. Other research suggests the potential for a positive impact on HE students in a counselling setting (larussi, 2013). There is a body of research exploring the ways in which health care students are taught to use MI in their professional contexts (c.f. Hinz, 2010; Lupu, Stewart, \& O'Neil, 2012) and it is possible that these findings could be utilised in the application of MI to enable teaching staff to work more effectively with students in HE. Lee et al. (2014) have developed a framework for the use of $\mathrm{Ml}$ in educational settings and there is potential for this to be adapted for use in HE. Our own research (Wells et al., 2013) examines the ways MI can be used in practice in HE. It sets out a student-centred, collaborative model that can be used to foster constructive relationships between student and teacher, and explored the ways in which MI can be used in teaching interactions.

Teaching involves negotiating complex dynamics of interpersonal relationships alongside intellectual content. Elsewhere (Wells et al., 2013) we argue that learning is a process of change and teaching is facilitation of this change. Ml assists teachers in creating a learning environment that is collaborative, empowering, engaging and motivating. Teaching is enhanced by understanding the emotional dimension of learning and this paper explores one set of principles that can be adapted for use in teaching.

This paper offers one set of useful techniques and the theories underpinning this approach. MI has value in higher education because it provides a technique to facilitate change in student behaviour patterns that are barriers to learning by using empathy and avoiding direct confrontation. Through using a cyclical discussion process outlined in our earlier paper (Wells et al., 2013), the student can consider the possibility of change, examine their goals, and explore barriers that prevent learning and examine other options.

\section{Challenges}

There are a number of challenges to the use of $\mathrm{Ml}$ in teaching in HE. The first is that using an approach developed in a health care setting turns education into therapy. There have been concerns that an emphasis in education on building self-esteem has lowered expectations while diminishing resilience and autonomy (Ecclestone \& Hayes, 2009). However, MI seeks to build autonomy and enhance resilience. Learning is social and contextual rather than simply behavioural (c.f. Pavlov, 1927; Skinner, 1938) or cognitive (Piaget, 1950). Learning is driven by social interaction and hence the social context is central 
to enable a process of change (Jarvis, 2006). Given this, it is an activity based on personal relationships and so it entails both risk and trust (Carless, 2009). Moreover it is a process of moving from one state to another. Disjuncture is the uncomfortable state when what is taken for granted no longer applies and we have to consider 'how', 'why' and 'what does this mean' and in so doing generate new explanations, knowledge or ways of doing (Jarvis, 2012). This is linked to cognitive dissonance since once a person is aware that two positions do not 'fit' and can hold them in tension, there is then the potential for learning by seeking solutions that reduce the dissonance.

Therapy is treatment intended to cure or relieve a disorder, either physical or mental. Education is not therapy because it firstly does not consider the learner (primarily) to be disordered and secondly does not accept that it has a cure for any possible disorder but rather that it can provide opportunities to understand or do something differently and hence to gain access to new knowledge, skills or dispositions.

Yet we do acknowledge the emotional element to education. It can be a disturbing process and can have unintended consequences (Britzman, 2003; Coren, 1997). For example, transition to HE can be challenging (Briggs, Clark, \& Hall, 2012). The combination of factors such as a commitment to an extensive period of education in which earning capacity is reduced yet costs are high, the assessment process in which students are judged against established (yet sometimes opaque) standards and for many students the move away from the family home and entry into adulthood can all provoke stress. One's sense of self and the interpersonal relationships associated with teaching are central. While we argue that education is not (nor should be) therapy, we maintain that cognitive approaches to education fails to take into account the emotional dimension. Ml provides one set of tools that acknowledge the emotional aspects of classroom interaction.

Another possible objection to $\mathrm{Ml}$ is the implications of 'reluctant' or 'resistant', implying a deficit, blame-laden approach. The terms resistant or reluctant are used to suggest that the student is experiencing some difficulty with the learning process but is not a normative position. The implication is not that it is the student's fault or that he/she does not have a right to resist. One of the key conditions of $\mathrm{Ml}$ is unconditional positive regard: the teacher seeks to understand the student's feelings and perspectives without judging, criticising or blaming (Rogers, 1951). However, acceptance should not be confused with approval of the behaviour. It is possible to understand behaviour without endorsing it. In $\mathrm{HE}$, we condone the student's right to challenge, question or ignore the teacher, the theories or the educational policies of the institution. Yet, while upholding students' right to self-determination, in a large institution there are consequences as these actions may result in interpersonal conflict, disciplinary action or academic failure. If these behaviours are explored and understood, and the student can weigh up the benefits and consequences of their behaviour and consider possible alternatives, there is potential for change. Alternatively, failing to accept the behaviour leaves us condemning it and if we punish, it may escalate (Brehm \& Brehm, 1981). Moreover, either ignoring or punishing the behaviour does not allow for any consideration of the student's point of view, nor does it allow the student to take responsibility for their own choices and hence become autonomous as a learner.

Another question regarding $\mathrm{Ml}$ is whether, by focusing upon the individual, the approach avoids any consideration of the social structures that influence the context of education. MI considers the individual student and their particular response to learning. One of the skills and tensions of being a teacher is to consider each student as an individual with needs and responses that are unique. However, the teacher also needs to consider this in the context of social structures such as gender, class, sexuality, ethnicity and so on. MI does not ignore or avoid these issues but engages in a discussion with students, acknowledging that both social structures and personal conditions can be barriers to success in education. MI does not purport to be a device for changing social structures but rather to enable students to either work with or against these structures in informed and conscious ways to enable learning. Ml operates on an immediate 'here and now' perspective. Social conditions impact on the here and now but are relatively intractable. $\mathrm{Ml}$ is a relatively pragmatic approach in that it acknowledges what can be changed and what is unchangeable (at least in the short term). In the university context, an MI approach would not deny structural barriers to success nor would it deny aspects of education such 
as university regulations, disciplinary cultures, departmental practices or social conventions. Helping students to manage their resistance to learning does not avoid or ignore the potential for challenging the social structures that may contribute towards a student's experiences of unwillingness to learn.

A final concern regarding $\mathrm{Ml}$ is that it promotes a compliant view of education rather than a more critical or emancipatory one. An emancipatory perspective has currently slipped from view but we argue is still significant. Freire (1970) argued for the need for learners to adopt a critical stance i.e. the preparedness to question. He suggested that learning is not simply a process of decoding and analysing but also critique and thus learning enabled insight into the cultural and political to empower change. Although Ml does not actively promote a struggle for change, neither does it refute it. It does not encourage one position over the other, although there is an implicit assumption that it is desirable that the student is able to achieve as much success as possible. Fundamental to $\mathrm{Ml}$ is the understanding that people are autonomous and able to make their own decisions, albeit, with support. It is an approach that aims to empower people to overcome behaviours that limit potential. It does this through enabling people to explore the possibilities open to them, including the benefits and consequences of their actions. So for example, a benefit of challenging the system may bring about change but a consequence may be that this will result in disciplinary interventions. By exploring these two positions, the person is holding the two extremes in tension and is therefore bringing the cognitive dissonance to the fore. The theory of cognitive dissonance holds that the person will then seek ways of reducing the dissonance by seeking solutions that in turn will reduce their ambivalence to learning.

\section{Implications and conclusions}

This paper examines the theoretical underpinnings of $\mathrm{MI}$ in its application to HE. While the actual practice of $\mathrm{MI}$ in $\mathrm{HE}$ is relatively new and untested, we argue that as a theory it has integrity and is congruent with current pedagogic practice. The practical application (Wells et al., 2013) points to ways in which MI can enable students to identify and then achieve their goals. It seeks to provide a tool to empower the student to be responsible for their own learning. It sees students and teachers as working collaboratively with each other. The use of MI by teachers in HE has not been extensively tested so there is a need for examination of the ways in which Ml can most effectively be introduced to teaching staff and utilised in educational contexts. The next step in this project is to outline empirical evidence for the use of MI in the classroom and to investigate the ways in which it needs to be adapted or reconceptualised and its strengths and weaknesses in an applied context.

\section{Disclosure statement}

No potential conflict of interest was reported by the authors.

\section{Notes on contributors}

Harvey Wells is a Lecturer in Clinical Communication with the Medical School at The University of Manchester. His background is as a psychotherapist, where he has used Motivational Interviewing to help make healthy behaviour changes. $\mathrm{He}$ is keen to see lecturers use these same techniques to support students to be more effective learners.

Anna Jones is Professor of Education at the Centre for Research in Lifelong Learning at Glasgow Caledonian University. Her research interests include disciplinary cultures, graduate attributes, teaching in higher education and medical education.

\section{References}

Aharonovich, E., Amrhein, P. C., Bisaga, A., Nunes, E. V., \& Hasin, D. S. (2008). Cognition, commitment language, and behavioral change among cocaine-dependent patients. Psychology of Addictive Behaviors, 22, 557-562.

Amrhein, P. C., Miller, W. R., Yahne, C. E., Palmer, M., \& Fulcher, L. (2003). Client commitment language during motivational interviewing predicts drug use outcomes. Journal of Consulting and Clinical Psychology, 71, 862-878. 
Arkowitz, H., \& Miller, W. R. (2008). Learning, applying, and extending motivational interviewing. In H. Arkowitz, H. A. Westra, W. R. Miller, \& S. Rollick (Eds.), Motivational interviewing in the treatment of psychological problems. Applications of motivational interviewing (pp. 1-25). New York, NY: Guilford Press.

Atkinson, C., \& Cryer S. C. (2015). Exploring the use of motivational interviewing with a disengaged primary-aged child. Educational Psychology in Practice, 31, 56-72.

Bem, D. J. (1972). Self-perception theory. In L. Berkowitz (Ed.), Advances in experimentalsocial psychology (pp. 1-62). New York, NY: Academic Press.

Boud, D. (Ed.). (1981). Developing student autonomy in learning. London: Kogan Page.

Brandes, D., \& Ginnis, P. (1994). A guide to student-centred learning. Oxford: Blackwell.

Brehm, S. S., \& Brehm, J. W. (1981). Psychological reactance: A theory of freedom and control. New York, NY: Academic Press.

Briggs, A. R. J., Clark, J., \& Hall, I. (2012). Building bridges: Understanding student transition to university. Quality in Higher Education, 18, 3-21.

Britzman, D. (2003). After-education: Anna Freud. Melanie Klein and psychoanalytic histories of learning. Albany: State University of New York Press.

Candy, P. C. (1991). Self-direction for lifelong learning: A comprehensive guide to theory and practice. San Francisco, CA: JosseyBass.

Carless, D. (2009). Trust, distrust and their impact on assessment reform. Assessment and Evaluation in Higher Education, $34,79-89$.

Carlson, R. (1989). Malcolm Knowles apostle of andragogy. Vita Scolasticae, 8, 217-234.

Clarke, K. M., \& Greenberg, L. S. (1986). Differential effects of the Gestalt two-chair intervention and problem solving in resolving decisional conflict. Journal of Counseling Psychology, 33, 11-15.

Coren, A. (1997). A psychodynamic approach to education. London: Sheldon Press.

Daugherty, M. (2008). A randomized trial of motivational interviewing with college students for academic success (Unpublished doctoral dissertation). The University of New Mexico, USA.

Davison, G. C., Tsujimoto, R. N., \& Glaros, A. G. (1973). Attribution and the maintenance of behavior change in falling asleep. Journal of Abnormal Psychology, 82, 124-133.

Dewey, J. (1916/2004). Democracy and education: An introduction to the philosophy of education. London: Macmillan.

Ecclestone, K., \& Hayes, D. (2009). The dangerous rise of therapeutic education. London: Routledge.

Enea, V., \& Dafinoiu, I. (2009). Motivational/solution-focused intervention for reducing school truancy among adolescents. Journal of Cognitive and Behavioral Psychotherapies, 9, 185-198.

Festinger, L. (1957). A theory of cognitive dissonance. Evanston, IL: Row Peterson.

Frank, J. D., \& Frank, J. (1961). Persuasion and healing: A comparative study of psychotherapy. Baltimore, MD: Johns Hopkins University Press.

Freire, P. (1970). Pedagogy of the oppressed. New York, NY: Seabury.

Frey, A. J., Cloud, R. N., Lee, J., Small, J. W., \& Seeley, J. R. (2011). The promise of motivational interviewing in school mental health. School Mental Health, 3, 1-12.

Frey, A. J., Lee, J., Small, J. W., Seeley, J. R., \& Feil, E. G. (2013). The motivational interviewing navigation guide: A process for enhancing teachers' motivation to adopt and implement school-based interventions. Advances in School Mental Health Promotion, 6, 1-18.

Frymier, A. B., Shulman, G. M., \& Houser, M. L. (1996). The development of a learner empowerment measure. Communication Education, 45, 181-199.

Funnell, M. M., \& Anderson, R. M. (2000). The problem with compliance in diabetes. JAMA, 284, 1709-1709.

Gray, R., Wykes, T., Edmonds, M., Leese, M., \& Gournay, K. (2004). Effect of a medication management training package for nurses on clinical outcomes for patients with schizophrenia: Cluster randomised controlled trial. The British Journal of Psychiatry, 185, 157-162.

Hadraba, H. (2011). The use of motivational interviewing within school counseling programs for academically unmotivated eighth grade students. (Unpublished doctoral dissertation). Oregon State University, Oregon, USA.

Hinz, J. G. (2010). Teaching dental students motivational interviewing techniques: Analysis of a third-year class assignment. Journal of Dental Education, 74, 1351-1356.

Houser, M. L., \& Frymier, A. B. (2009). The role of student characteristics and teacher behaviors in students' learner empowerment. Communication Education, 58, 35-53.

larussi, M. M. (2013). Examining how motivational interviewing may foster college student development. Journal of College Counseling, 16, 158-175.

Jarvis, P. (2006). Towards a comprehensive theory of human learning: Lifelong learning and the learning society (Vol. 1). London and New York: Routledge.

Jarvis, P. (2012). Learning from everyday life. Human and social studies research and practice, 1, 1-20.

Jones, A., \& Wells, H. (2013). Motivational interviewing in higher education classrooms: An interdisciplinary adventure. In F. Deepwell \& C. Buckley (Eds.), Celebrating the scholarship of academic development, SEDA Special 35 (pp. 23-26). London: SEDA.

Kittles, M., \& Atkinson, C. (2009). The usefulness of motivational interviewing as a consultation and assessment tool for working with young people. Pastoral Care in Education, 27, 241-254. 
Kohut, H. (1971). The analysis of the self. Chicago, IL: University of Chicago Press.

Kolb, D. A. (1984). Experiential learning: Experience as the source of learning and development. Englewood Cliffs, NJ: PrenticeHall.

Lee, J. S., Frey, A. J., Small, J. W., Walker, H., Golly, A., Feil, E., ... Rutledge, A. (2014). Motivational interviewing in support of teacher behaviour change. In E. McNamara (Ed.), Motivational interviewing with children and young people II: Issues and further applications (pp. 83-102). Ainsdale: Positive Behaviour Management.

Lupu, A. M., Stewart, L., \& O’Neil, C. (2012). Comparison of active-learning strategies for motivational interviewing skills, knowledge, and confidence in first-year pharmacy students. American Journal of Pharmaceutical Education, 76, 1-7.

Mahoney, M. J. (1991). Human change processes: The scientific foundations of psychotherapy. New York, NY: Basic Books.

Manthey, T. (2011). Using motivational interviewing to increase retention in supported education. American Journal of Psychiatric Rehabilitation, 14, 120-136.

McNamara, E. (1992). Motivational interviewing: Tlie gateway to pupil self-management. Pastoral Care in Education, 10, 22-28.

Mezirow, J. (Ed.). (2000). Learning as transformation: Critical perspectives on a theory in progress. San Francisco, CA: Jossey-Bass.

Miller, W. R. (1983). Motivational interviewing with problem drinkers. Behavioural Psychotherapy, 11, 147-172.

Miller, W. R., Benefield, R. G., \& Tonigan, J. S. (1993). Enhancing motivation for change in problem drinking: A controlled comparison of two therapist styles. Journal of Consulting and Clinical Psychology, 61, 455-461.

Miller, W. R., \& Moyers, T. B. (2006). Eight stages in learning motivational interviewing. Journal of Teaching in the Addictions, 5, 3-17.

Miller, W. R., \& Rollnick, S. (2002). Motivational interviewing: Preparing people for change (2nd ed.). New York, NY: Guilford Press.

Miller, W. R., \& Taylor, C. A. (1980). Relative effectiveness of bibliotherapy, individual and group self-control training in the treatment of problem drinkers. Addictive Behaviors, 5, 13-24.

Pavlov, I. P. (1927). Conditioned reflexes: An investigation of the physiological activity of the cerebral cortex. London: Oxford University Press.

Piaget, J. (1950). The psychology of intelligence. London: Routledge.

Prochaska, J. O., \& Prochaska, J. M. (1991). Why don't people change? Why don't continents move? Journal of Psychotherapy Integration, 9, 83-102.

Reinke, W. M., Herman, K. C., \& Sprick, R. (2011). Motivational interviewing for effective classroom management: The classroom check-up. New York, NY: Guilford Press.

Rogers, C. R. (1951). Client-centred therapy: Its current practice, implications and theory (p. 491). Boston, MA: Houghton Mifflin.

Rollnick, S., \& Miller, W. R. (1995). What is motivational interviewing? Behavioural and Cognitive Psychotherapy, 23, 325-334.

Sellman, J. D., Sullivan, P. F., Dore, G. M., Adamson, S. J., \& MacEwan, I. (2001). A randomized controlled trial of motivational enhancement therapy (MET) for mild to moderate alcohol dependence. Journal of Studies on Alcohol, 62, 389-396.

Sheldon, L. A. (2010). Using motivational interviewing to help your students. Thought and Action, Fall, 153-158.

Shepard, S., Herman, K. C., Reinke, W. M., \& Frey, A. (2014). Motivational interviewing in schools: Strategies for engaging parents, teachers, and students. New York, NY: Springer.

Skinner, B. (1938). Behaviour of organisms. New York, NY: Appleton-Century-Crofts.

Sorrentino, R. M., \& Higgins, E. T. (Eds.). (1996). Handbook of motivation and cognition: The interpersonal context (pp. 118-147). New York, NY: Guilford Press.

Strait, G. G., Smith, B. H., McQuillin, S., \& Terry, John (2012). A randomized trial of motivational interviewing to improve middle school students' academic performance. Journal of Community Psychology, 40, 1032-1039.

Terry, J., Smith, B., Strait, G., \& McQuillin, S. (2013). A randomized trial of motivational interviewing to improve middle school students' academic performance: A replication study. Journal of Community Psychology, 41, 902-909.

Thomas, K., \& Velthouse, B. (1990). Cognitive elements of empowerment: An'interpretive' mode of intrinsic task motivation. Academy of Management Review, 15, 666-681.

Vygotsky, L. (1978). Interaction between learning and development. Readings on the development of children, 23, 34-41.

Wampold, B. E. (2001). The great psychotherapy debate: Models, methods and findings. Mahwah, NJ: Lawrence Erlbaum Publishers.

Welch, G., Rose, G., \& Ernst, D. (2006). Motivational interviewing and diabetes: What is it, how is it used, and does it work? Diabetes Spectrum, 19, 5-11.

Wells, H., Jones, A., \& Jones, S. (2013). Teaching reluctant students: Using the principles and techniques of motivational interviewing to foster better student-teacher interactions. Innovations in Education and Teaching International, 51, 175-184.

White, W. L., \& Miller, W. R. (2007). The use of confrontation in addiction treatment: History, science and time for change. Counselor, 8, 12-30. 